\title{
Insecticidal and Neuroblocking Activities of Thiacloprid and Its Acyclic Analogues and Their Related Cyanoguanidine Derivatives
}

\author{
Shinzo KagABU, ${ }^{*}$ Akiko AzUMA and Keiichiro Nishimura ${ }^{\dagger}$ \\ Department of Chemistry, Faculty of Education, Gifu University, Gifu 501-1193, Japan \\ ${ }^{\dagger}$ Research Institute for Advanced Science and Technology, Osaka Prefecture University, \\ Gakuen-cho, Sakai, Osaka 599-8570, Japan
}

(Received March 15, 2002 ; Accepted May 2, 2002)

\begin{abstract}
Acyclic analogues of thiacloprid and related cyanoguanidine derivatives were prepared. Their insecticidal activity against the American cockroach was determined by the injection method with or without metabolic inhibitor(s). Thiacloprid along with two cyanoguanidine analogues showed the highest insecticidal potency without the inhibitors, which was one twentieth that of imidacloprid. Metabolic inhibitors increased the activity by a factor of up to 100 for sulfur-containing compounds including thiacloprid, while the effect for the cyanoguanidine derivatives was much smaller. Most of the test compounds elicited impulses in cockroach central nerves with an initial excitation and subsequent block. Thiacloprid and its acyclic analogue were on a par with imidacloprid for blocking potency. As the blocking activity increases, the insecticidal activity measured with the metabolic inhibitors tends to strengthen.
\end{abstract}

Key words: chloronicotinyl insecticide, thiacloprid, imidacloprid, American cockroach, insecticidal activity, neuroblocking activity.

\section{INTRODUCTION}

The last decade opened the era of chloronicotinyl insecticides as a major new class of highly effective and widely used insecticides for crop protection and veterinary pest control. ${ }^{1,2)}$ Since the first product of this class, imidacloprid (1), was marketed, we have seen how the structural modification and derivation of the prototype backbone can bring latent biological properties to light and impart different ecotoxicological qualities from the original molecule. ${ }^{2}$ We could name nitenpyram $(3)^{3)}$ and acetamiprid $(4)^{4)}$ as the fruits of sophisticated molecular design. In 2000 another new type of structure, thiacloprid (2), was added to this class. This newcomer, with a cyanoiminothiazolidine skeleton instead of the original nitroiminoimidazolidine, has been reported to display distinguishing field performance. ${ }^{5,6}$

The present study aims to acquire a fundamental physiological knowledge of thiacloprid and two acyclic isosteres. We included further ten acyclic cyanoguanidine molecules, a mixed-type of nitenpyram and acetamiprid, to see how incorporated structural elements influence the biological profiles. Our

\footnotetext{
* To whom correspondence should be addressed.

E-mail: kagabus@cc.gifu-u.ac.jp
}

approach is two-pronged. First, we determined insecticidal activity against American cockroach by the injection method to eliminate the factor of penetration through the cuticle. The insecticidal activity of compounds should be governed by various factors: penetration through the cuticle, transport within the insect body, metabolic inactivation, binding to the target sites, intrinsic activity at the target sites, and others. To analyze the role of metabolism in insecticidal activity, metabolic inhibitors were used. Second, we measured the nerve impulses in excised American cockroach nerve preparations. Evidence has accumulated to suggest that chloronicotinyl insecticides induce in insect neurons transient inward currents resembling ACh-induced currents followed by blocking of the current in the continued presence of the insecticides. ${ }^{7-11)}$ We showed previously for imidacloprid-related compounds that the insecticidal activity reflects better neuroblocking potency rather than neuroexcitatory activity. ${ }^{12,13)}$ We used this estimation for the insecticidal activity of the present compounds.

\section{MATERIALS AND METHODS}

\section{Synthesis of Compounds}

All melting points (mp) are uncorrected. NMR spectra were obtained by a Varian Gemini 2000 C/H (400 




1 (imidacloprid): $X=\mathrm{NNO}_{2}, Y=\mathrm{NH}$ 2 (thiacloprid): $X=N C N, Y=S$<smiles>[Y]C([R])N([R])Cc1ccc(Cl)nc1</smiles>

3 (nitenpyram): $R_{1}=E t, R_{2}=N H M e, X=\mathrm{CHNO}_{2}$ 4 (acetamiprid): $R_{1}=M e, R_{2}=M e, X=N C N$
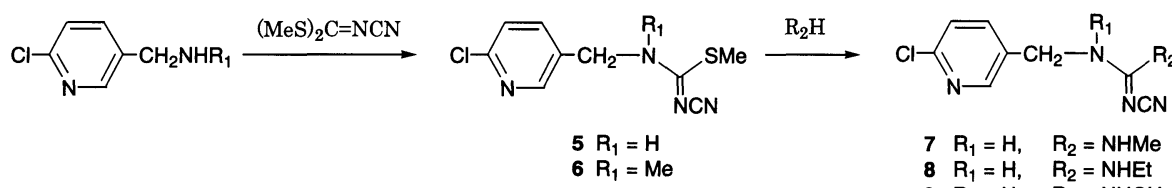

$7 \quad R_{1}=H, \quad R_{2}=\mathrm{NHMe}$ $8 \quad R_{1}=H, \quad R_{2}=$ NHEt $9 \mathrm{R}_{1}=\mathrm{H}, \quad \mathrm{R}_{2}=\mathrm{NHCH}_{2} \mathrm{C}_{6} \mathrm{H}_{5}$

$10 \mathrm{R}_{1}=\mathrm{H}, \quad \mathrm{R}_{2}=\mathrm{NMe}_{2}$

$11 R_{1}=\mathrm{Me}, \mathrm{R}_{2}=\mathrm{NH}_{2}$

$12 R_{1}=\mathrm{Me}, \mathrm{R}_{2}=\mathrm{NHMe}$

$13 \mathrm{R}_{1}=\mathrm{Me}, \mathrm{R}_{2}=\mathrm{NHEt}$

$14 \mathrm{R}_{1}=\mathrm{Me}, \mathrm{R}_{2}=\mathrm{NHCH}_{2} \mathrm{C}_{6} \mathrm{H}_{5}$

$15 \mathrm{R}_{1}=\mathrm{Me}, \mathrm{R}_{2}=\mathrm{NMe}_{2}$

Fig. 1 Imidacloprid (1), thiacloprid (2), nitenpyram (3), acetamiprid (4) and the scheme for praparing compounds 5-15.

Table $1 \quad{ }^{1} \mathrm{H}-\mathrm{NMR}$ spectral data of the newly prepared compounds. ${ }^{\text {a) }}$

\begin{tabular}{|c|c|c|c|c|}
\hline No. & $\mathrm{R}_{1}$ & $\mathrm{R}_{2}$ & $\mathrm{CH}_{2}$ & Pyridine \\
\hline 2 & $3.42(2 \mathrm{H}, \mathrm{m})$ & $3.83(2 \mathrm{H}, \mathrm{m})$ & $4.64(\mathrm{~s})$ & $7.37(\mathrm{~d}, \underline{J}=8.0), 7.68(\mathrm{dd}, \underline{J}=8.0 / 2.6), 8.32(\mathrm{~d}, \underline{J}=2.6)$ \\
\hline $5^{\mathrm{b})}$ & $8.96(\mathrm{NH}, \mathrm{bs})$ & $2.63(3 \mathrm{H}, \mathrm{s})$ & $4.51(\mathrm{~s})$ & $7.51(\mathrm{~d}, \underline{J}=8.4), 7.80(\mathrm{dd}, \underline{J}=8.4 / 2.2), 8.36(\mathrm{~d}, \underline{J}=2.2)$ \\
\hline 6 & $3.20(3 \mathrm{H}, \mathrm{s})$ & $2.86(3 \mathrm{H}, \mathrm{s})$ & $4.80(\mathrm{~s})$ & $7.36(\mathrm{~d}, \underline{J}=8.4), 7.62(\mathrm{dd}, \underline{J}=8.4 / 2.6), 8.30(\mathrm{~d}, \underline{J}=2.6)$ \\
\hline $7^{\mathrm{b})}$ & $7.59(\mathrm{NH}, \mathrm{bs})$ & $2.70(3 \mathrm{H}, \mathrm{d}, \underline{J}=4.4), 7.15(\mathrm{NH}, \mathrm{bs})$ & $4.34(\mathrm{~d}, \underline{J}=5.8)$ & $7.49(\mathrm{~d}, \underline{J}=8.4), 7.75(\mathrm{dd}, \underline{J}=8.4 / 1.8), 8.32(\mathrm{~d}, \underline{J}=1.8)$ \\
\hline $8^{c)}$ & $7.10(\mathrm{NH}, \mathrm{bs})$ & $1.15(3 \mathrm{H}, \mathrm{t}, \underline{J}=6.9), 3.31(2 \mathrm{H}, \mathrm{m}), 6.46(\mathrm{NH}, \mathrm{bs})$ & $4.50(\mathrm{~d}, \underline{J}=5.8)$ & $7.40(\mathrm{~d}, \underline{J}=8.1), 7.80(\mathrm{dd}, \underline{J}=8.1 / 0.3), 8.35(\mathrm{~d}, \underline{J}=0.3)$ \\
\hline $9^{\mathrm{b})}$ & $8.91(\mathrm{NH}, \mathrm{bs})$ & $\begin{array}{l}4.50(2 \mathrm{H}, \mathrm{s}), 7.20(1 \mathrm{H}, \mathrm{m}), 7.51(\mathrm{~m}, 2 \mathrm{H}) \\
7.19(\mathrm{NH}, \mathrm{bs}), 7.70(2 \mathrm{H}, \mathrm{m})\end{array}$ & $4.35(\mathrm{~d}, \underline{J}=5.9)$ & $7.47(\mathrm{~d}, \underline{J}=8.4), 7.80(\mathrm{dd}, \underline{J}=8.4 / 2.2), 8.36(\mathrm{~d}, \underline{J}=2.2)$ \\
\hline 10 & . & $3.07(6 \mathrm{H}, \mathrm{s})$ & $4.54(\mathrm{~s})$ & $7.29(\mathrm{~s}), 7.72(\mathrm{~d}, \underline{J}=8.0), 8.32(\mathrm{~s})$ \\
\hline $11^{\mathrm{b})}$ & $2.90(3 \mathrm{H}, \mathrm{s})$ & $7.19(\mathrm{NH}, \mathrm{bs})$ & $4.57(\mathrm{~s})$ & $7.52(\mathrm{~d}, \underline{J}=8.0), 7.70(\mathrm{dd}, \underline{J}=8.0 / 2.2), 8.29(\mathrm{~d}, \underline{J}=2.2)$ \\
\hline $12^{\mathrm{b})}$ & $\begin{array}{l}3.13 \quad(3 \mathrm{H}, \mathrm{d}, \\
\underline{J}=3.3)\end{array}$ & $6.30(\mathrm{NH}, \mathrm{bs})$ & $4.60(\mathrm{~s})$ & $7.32(\mathrm{~d}, \underline{J}=8.0), 7.65$ (dd, $\underline{J}=8.0 / 2.2), 8.26(\mathrm{~d}, \underline{J}=2.2)$ \\
\hline 13 & $2.93(3 \mathrm{H}, \mathrm{s})$ & $\begin{array}{l}1.26(3 \mathrm{H}, \mathrm{t}, \underline{J}=7.0), 3.63(2 \mathrm{H}, \mathrm{q}, \underline{J}=7.0) \\
5.80(\mathrm{NH}, \mathrm{bs})\end{array}$ & $4.61(\mathrm{~s})$ & $7.30(\mathrm{~d}, \underline{J}=8.0), 7.66(\mathrm{~d}, \underline{J}=8.0)$ \\
\hline 14 & $2.90(3 \mathrm{H}, \mathrm{s})$ & $4.69(2 \mathrm{H}, \mathrm{d}, \underline{J}=5.5), 7.30-7.33(5 \mathrm{H}, \mathrm{m})$ & $4.59(\mathrm{~s})$ & $7.28(\mathrm{~d}, \underline{J}=8.0), 7.56(\mathrm{dd}, \underline{J}=8.0 / 2.2), 8.21(\mathrm{~d}, \underline{J}=2.2)$ \\
\hline 15 & $2.81(3 \mathrm{H}, \mathrm{s})$ & $3.04(6 \mathrm{H}, \mathrm{s})$ & $4.51(\mathrm{~s})$ & $7.35(\mathrm{~d}, \underline{J}=8.4), 7.73(\mathrm{dd}, \underline{J}=8.4 / 2.6), 8.31(\mathrm{~d}, \underline{J}=2.6)$ \\
\hline
\end{tabular}

a) In $\mathrm{CDCl}_{3}$ unless stated otherwise. ${ }^{\text {b) }}$ In DMSO- $\mathrm{d}_{6}$. ${ }^{\text {c) }}$ In acetone- $\mathrm{d}_{6}$.

$\mathrm{MHz})$. The chemical shifts were recorded in $\delta(\mathrm{ppm})$ and the coupling constants $J$ in $\mathrm{Hz}$. Thiacloprid was prepared according to reported procedures. ${ }^{5}$ ) The other products were obtained based on the scheme in Fig. 1. The proton NMR spectral data for the prepared compounds are given in Table 1 and the melting points are listed in Table 2. Log $P$ values of synthesized compounds were measured in 1-octanol+water at $23^{\circ} \mathrm{C}$ $( \pm 0.2)$ using the flask shake method and are listed in Table 2 .

\section{Biological Tests}

\subsection{Chemicals}

Reagent-grade piperonyl butoxide (PB) purchased from Tokyo Kasei Kogyo Co., Tokyo, Japan was used as an inhibitor of oxidative metabolism. NIA 16388 (propargyl propyl benzenephosphonate; NIA), origi- nally reported as an inhibitor of the hydrolytic metabolism of tetramethrin pyrethroid ${ }^{14)}$ was the same sample used in our previous studies. ${ }^{12,13,15,16)}$

\subsection{Insecticidal assay}

The insecticidal assay against male adult American cockroaches, Periplaneta americana L., was conducted as described previously. ${ }^{12,13,15,16)}$ Various volumes (1-10 $\mu l)$ of each compound dissolved in methanol were injected into the abdomen of a cockroach. Methanol alone in this range did not have any toxic effect. Details of the dosage were fundamentally the same as described previously. ${ }^{15)}$ The doses varied by 1.25 fold. In some experiments, a methanol solution $(1 \mu \mathrm{l})$ containing PB $(50 \mu \mathrm{g})$ and NIA $(50 \mu \mathrm{g})$ or a mixture of these metabolic inhibitors ( $50 \mu \mathrm{g}$ for each) was injected $1 \mathrm{hr}$ before injection of the test compound. The metabolic inhibitors in 
Table 2 Physical properties and biological activities of tested compounds.

\begin{tabular}{|c|c|c|c|c|c|c|c|c|c|}
\hline & \multicolumn{6}{|c|}{ Insecticidal activity, $\left.\mathrm{MLD}(\mathrm{nmol})^{\mathrm{b}}\right)$} & \multirow{2}{*}{$\begin{array}{c}\left.\text { Neuroblocking potency }{ }^{c}\right) \\
\text { BC }(\mu \mathrm{M})\end{array}$} \\
\hline \multicolumn{2}{|c|}{$\begin{array}{l}\text { Compound } \\
\text { No. } \quad \mathrm{mp}\left({ }^{\circ} \mathrm{C}\right)\end{array}$} & \multirow{2}{*}{$\frac{\log \underline{P}}{1.20( \pm 0.03)}$} & \multirow{2}{*}{\begin{tabular}{|c|} 
Alone \\
21
\end{tabular}} & \multicolumn{2}{|c|}{$+\mathrm{PB}^{\mathrm{d})}$} & \multicolumn{2}{|c|}{$+\mathrm{NIA}^{\mathrm{d}}$} & \multirow{2}{*}{$\begin{array}{c}+(\mathrm{PB}+\mathrm{NIA}) \\
0.21(100)\end{array}$} & \\
\hline $2^{\mathrm{e})}$ & $138-139$ & & & 5.9 & (4) & 0.46 & (46) & & $2.6( \pm 0.7)$ \\
\hline 5 & $200-202$ & $1.27( \pm 0.04)$ & $>83$ & 21 & (4) & 0.83 & $(>100)$ & $0.66(>130)$ & $1.7( \pm 0.9)$ \\
\hline 6 & $70-73$ & $1.40( \pm 0.02)$ & 160 & 71 & (2) & 6.3 & (25) & $2.5 \quad(64)$ & $6.0( \pm 0.6)$ \\
\hline 7 & $207-209$ & $0.84( \pm 0.01)$ & $>180$ & 180 & $(>1)$ & 18 & $(>10)$ & $8.9(>20)$ & $110 \quad( \pm 15)$ \\
\hline 8 & $145-147$ & $0.86( \pm 0.09)$ & $>170$ & & & & & $>170$ & $>170$ \\
\hline 9 & $171-174$ & - & $>66$ & & & & & $(>1)$ & $150 \quad( \pm 8)$ \\
\hline 10 & $132-135$ & $0.66( \pm 0.09)$ & $>170$ & & & & & $(>1)$ & $>170$ \\
\hline 11 & $176-178$ & $0.71( \pm 0.04)$ & 22 & 14 & (2) & 0.71 & (31) & $1.2 \quad(18)$ & $9.6( \pm 0.5)$ \\
\hline 12 & $123-126$ & $0.78( \pm 0.01)$ & 68 & & & & & (1) & $>170$ \\
\hline 13 & $102-104$ & $1.02( \pm 0.03)$ & 26 & & & & & $(0.6)$ & $>160$ \\
\hline 14 & $112-114$ & $1.32( \pm 0.02)$ & 81 & 25 & (3) & 8.1 & (10) & $6.3 \quad(13)$ & $( \pm 9)$ \\
\hline 15 & 73-75 & $0.66( \pm 0.01)$ & 320 & 200 & (2) & 32 & (10) & (16) & $>400$ \\
\hline $\mathbf{1}^{\mathrm{f})}$ & & $0.60^{8}$ & 1.1 & 0.55 & (2) & 0.19 & (6) & $0.07 \quad(16)$ & $2.3( \pm 0.6)$ \\
\hline
\end{tabular}

a) Values in parentheses indicate the synergistic ratio calculated against the MLD determined under "Alone." b) The value has a deviation range of 0.64 to 1.6fold. c) The values in parentheses indicate the range of errors estimated from the standard deviation in terms of $\log (1 / \mathrm{BC})$. d) Not tested for blanks. e) Thiacloprid. ${ }^{\text {f) }}$ Imidacloprid. ${ }^{\text {g) }}$ Ref. 16.

these amounts had no toxic effect. Three insects were used to test each dose of each compound and were kept at $22-25^{\circ} \mathrm{C}$ for $24 \mathrm{hr}$ after injection. The minimum dose at which two of three insects were considered to be killed was taken as the minimum lethal dose (MLD in mol). Paralyzed insects were also counted as killed, because they did not recover. The MLD values for the test compounds are listed in Table 2. Each value is the mean of at least two experiments with a deviation of 0.64 to 1.6 -fold.

\subsection{Neurophysiological assay}

The neurophysiological test of the compounds was conducted as described previously. ${ }^{12,13}$ In brief, a nerve preparation containing the abdominal fifth and sixth ganglia of a male adult American cockroach was excised and placed in a saline solution. One of two bundles of the nerve cord on the thoracic side was taken up with saline into a glass tube, in which a silver wire was set as an electrode. As the reference electrode, another wire was set outside the cut end of the tube. The silver wires were thinly coated with silver chloride. The number of spontaneous discharges that were larger than approximately $15 \mu \mathrm{V}$ was consecutively counted with a pulse counter (MET-1100, Nihon Koden, Tokyo, Japan) for every $30 \mathrm{sec}$. The frequency was usually quite high for a few minutes after setting, and then normally subsided. When the frequency decreased in the range of 30-400 counts per $30 \mathrm{sec}$ for $5 \mathrm{~min}$ or more, the saline solution was exchanged for another saline containing a test compound dissolved in methanol. The final concentration of methanol was lower than $1 \%(\mathrm{v} / \mathrm{v})$, which did not affect the nerve activity. Measurements were conducted at $22-25^{\circ} \mathrm{C}$.

\section{RESULTS AND DISCUSSION}

Thiacloprid (2) showed strong insecticidal activity without the metabolic inhibitors with an MLD value of $21 \mathrm{nmol}$, one twentieth that of imidacloprid (Table 2). The same level of activity was observed for compounds 11 and 13, and slightly less for compounds 12 and 14. The other substituent combinations reduced the activity substantially.

The $\log P$ value (1.20) of thiacloprid (2) was larger than that (0.6) of imidacloprid (1), and sulfur-containing compounds 5 and 6 had higher partitions than the corresponding amine derivatives (Table 2). However, we could not find any definite relationship between the insecticidal activity and the molecular hydrophobicity $\log P$.

To eliminate the metabolic factor as far as possible, some of the test compounds were injected with each of PB and NIA or a mixture of these two metabolic inhibitors. With $\mathrm{PB}$, the activity was increased by a synergistic ratio of 2-4 (Table 2). The increase was greater with NIA than with $\mathrm{PB}$. It is remarkable that compounds $\mathbf{2 , 5}$ and 6 increased the ratios to more than 60 with both inhibitors. This result may be partly ascribed to the vulnerability of alkylthio groups to oxidizing metabolic systems, which would lead to their oxidation to sulfoxides in the insect body. However, how can we explain the far larger contribution by NIA than PB to the total synergist effect? We have no supporting experimental evidence for the present molecular system, but it is well documented that the alkylthio group is apt to leave under SN2 conditions. ${ }^{16)}$ Replacement of the alkylthio group on the isothiourea carbon by some bionucleophiles like amine, alcohol and thiol would take place readily. The 
high synergist ratio with NIA for primary amino derivative 11 is understandable from its ready hydrolytic tendency. Another reason for the smaller contribution of PB is the following. The cyanoguanidine moiety is made electronically deficient by the force of the strong electron-withdrawing cyano group in the conjugation. Oxidation of the partially positive framework would be a minor metabolic step. In fact PB was reported to increase the potency of imidacloprid-related molecules to a lesser degree than NIA. ${ }^{12,13,16)}$ The synergists did not affect the other compounds as much. The synergistic ratios with both metabolic inhibitors were between 10 and 20 for compounds 7, 11, 14 and 15 at a similar range of imidacloprid concentrations, while those for compounds 8-10, 12 and 13 were practically nil.

Under the conditions with PB and NIA, compound 5 $\left(\mathrm{R}_{1}=\mathrm{H}\right)$ was more active than the corresponding $N$-Me derivative (6) having the same other substituent (Table 2). A similar trend was observed for compounds 7 and 12. However, the reverse was the case for compounds 8 vs. 13,9 vs. 14, and 10 vs. 15 . Thus, among compounds 7-10 having $R_{1}=H$, the smallest substituent as $R_{2}(=$ $\mathrm{NHMe}$ ) gave the most active compound 7. In contrast, in the series of compounds 11-15 $\left(\mathrm{R}_{1}=\mathrm{Me}\right)$, the bulkiest substituent as $\mathrm{R}_{2}\left(=\mathrm{NHCH}_{2} \mathrm{C}_{6} \mathrm{H}_{5}\right)$ seemed to be most favorable for the activity except for compound 11. This is an interesting finding, but cannot be explained at present.

To evaluate the activity at the target site, we measured the nerve effects of the compounds on the nerves using an

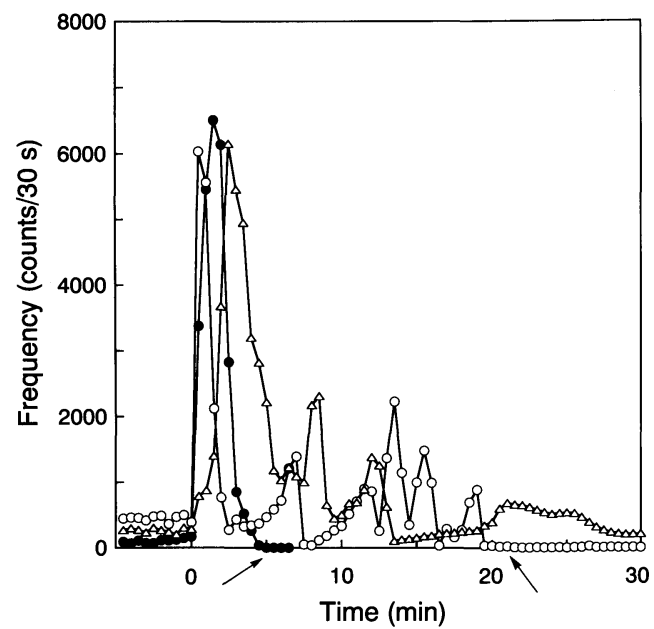

Fig. 2 Time courses of the effect of compound 7 on spontaneous discharges in the excised central nerve cords of American cockroaches.

After counting the cumulative number of spontaneous discharges every $30 \mathrm{sec}$ for $5 \mathrm{~min}$, the saline was exchanged with saline containing the compound at $1.7 \times 10^{-4} \mathrm{M}(\Theta), 5.8 \times$ $10^{-5} \mathrm{M}(\bigcirc)$ and $1.7 \times 10^{-5} \mathrm{M}(\triangle)$. The time of the exchange was defined as zero time and the number of discharges was similarly counted. Arrows indicate the "blocked" points. electrophysiological method. Compound 7 markedly increased the frequency of impulses in the nerve preparation immediately after the start of treatment at $10^{-5} \mathrm{M}$, followed by a drop to a level lower than the control (Fig. 2). This biphasic episode is similar to that induced by imidacloprid and related compounds. ${ }^{12,13,16)}$ In Fig. 2, each symbol indicates cumulative counts of spike frequencies for every $30 \mathrm{sec}$ in each nerve preparation. Previously, we found that neuroblocking activity is a more reliable parameter than the excitatory activity to correlate with the insecticidal activity. ${ }^{13)}$ Thus, we only evaluated the neuroblocking activity of the compounds tested in this study. To evaluate the blocking activity of compound $\mathbf{7}$, the time to the first subsidence to a level lower than 10 counts per $30 \mathrm{sec}$, which was defined as $t$ in min, was determined for each nerve preparation. The nerve preparation that was "blocked" scarcely gave impulses of more than 10 counts $/ 30 \mathrm{sec}$, again, for each concentration. Usually more than three nerve preparations were used. The irregular nerve preparations were numbered normally less than two to obtain the reliable data. Nerve preparations that produced an extraordinarily high or low value in terms of $\log t$ were not used. From the concentration-response relationship of the averaged value (Fig. 3), the concentration required to reach 1 in terms of $\log t$ was determined and was defined as BC. The reliability of the relationship for this and related activities was previously confirmed. ${ }^{13)}$ The $\mathrm{BC}$ values (in $\mu \mathrm{M}$ ) for compound 7 and other tested compounds are listed in Table 2. Thiacloprid (2) displayed a neuroblocking potency comparable to imidacloprid (1) (Table 2). Alicyclic thiacloprid isoster (5) had a conspicuously strong blocking effect with a $\mathrm{BC}$ value of 1.7 $\mu \mathrm{M}$, making it slightly more active than imidacloprid (1). Compounds $\mathbf{6}$ and $\mathbf{1 1}$ also showed good potency, but

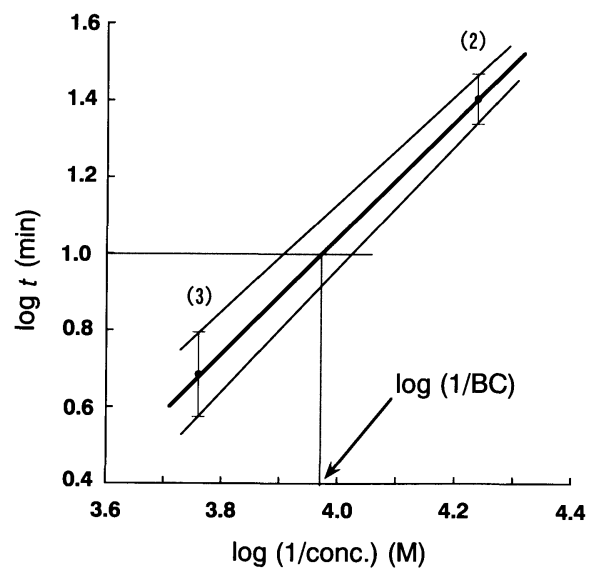

Fig. 3 Dose-response relation of compound 7 for the subsidence in spontaneous discharges in the central nerve cords of the American cockroach.

The vertical line shows the standard deviation for the number of determinations indicated in the parentheses. 
were significantly weaker than compound $\mathbf{5}$. The other compounds were so weak that a concentration of over $100 \mu \mathrm{M}$ was used for the blocking. We have no direct information about why alkylthio compounds $(5,6)$ tend to display lower BC values with a higher potency than the corresponding amino derivatives $(\mathbf{7}, \mathbf{1 2})$ carrying the smallest substituent $\mathrm{R}_{2}$ (=NHMe).

The insecticidal activity measured with both metabolic inhibitors increased roughly in parallel with the neuroblocking activity (Table 2). The nAChR, which is supposed to be the target site of the present class of compounds, can exist in multiple states, i.e. resting, active (open) and desensitized. Insecticidal measurements reflect an overall interaction of ligands with receptor states over a time scale of minutes to hours, whereas electrophysiological studies measure the interaction of the ligands with the resting and/or active states. The present class of compounds interacted with the nAChR of insects when they were injected, causing excitation and a subsequent block of the nervous system as was observed in the in vitro experiments (Fig. 2). Insects usually quivered shortly after the injection, and then recovered from the symptom or proceeded to undergo paralysis, depending on the injected dose. The paralysis would be the stage in which the nAChR was desensitized. Therefore, the longer-span insecticidal term, which was measured under conditions where the metabolic inactivation factor was mostly eliminated, could be correlated with the neuroblocking activity term. The hydrophobicity of compounds represented by $\log P$ could be used to significantly correlate insecticidal and neuroblocking activities, as was done previously. ${ }^{13)}$

In conclusion, thiacloprid had a clear agonistic effect on the nAChR of American cockroaches at a very low concentration comparable to that of imidacloprid. Acyclic thioether analogs of thiacloprid possess potent insecticidal activity, providing an approach to insecticide design in light of these bioisosteres.

\section{ACKNOWLEDGMENTS}

We wish to thank Earth Chemical Co., Ltd. for donating American cockroaches.

\section{REFERENCES}

1) S. Kagabu: Rev. Toxicol. 1, 75-129 (1997).

2) I. Yamamoto and J. E. Casida, ed. "Nicotinoid Insecticides and the Nicotinic Acetylcholine Receptor," Springer, Tokyo, 1999.

3) A. Akayama and I. Minamida: "Nicotinoid Insecticides and the Nicotinic Acetylcholine Receptor," ed. by I. Yamamoto and J. E. Casida, Springer, Tokyo, pp. 127-148, 1999.

4) T. Yamada, H. Takahashi and R. Hatano: "Nicotinoid
Insecticides and the Nicotinic Acetylcholine Receptor," ed. by I. Yamamoto and J. E. Casida, Springer, Tokyo, pp. 149-176, 1999.

5) K. Shiokawa, S. Tsuboi, S. Kagabu, S. Sasaki, K. Moriya and Y. Hattori (Nihon Tokushu Noyaku Seizo Co., Ltd.): Jpn. Tokkyo Koho JP 62-207266 (1987).

6) A. Elbert, C. Erdelen, J. Kühnhold, R. Nauen, H. W. Schmidt and Y. Hattori: "Proc. Brighton Crop Prot. Conf. Pests and Diseases,” BCPC, Farnham, Survey, UK, pp. 2126, 2001.

7) M. E. Schroeder and R. F. Flattum: Pestic. Biochem. Physiol. 22, 148-160 (1984).

8) D. B. Sattelle, S. D. Buckingham, K. A. Wafford, S. M. Sherby, N. M. Bakry, A. T. Eldefrawi and M. E. Eldefrawi: Proc. Roy. Soc. Lond. B237, 501-514 (1989).

9) R. Zwart, M. Oortgiesen and H. P. M. Vijverberg: Pestic. Biochem. Physiol. 48, 202-213 (1994).

10) M. Tomizawa and J. E. Casida: Pest Manag. Sci. 57, 914$922(2001)$

11) K. Matsuda, S. D. Buckingham, D. Kleier, J. J. Rauh, M. Grauso and D. B. Sattelle: Trends Pharmacol. Sci. 22, 573580 (2001).

12) K. Nishimura, M. Tanaka, K. Iwaya and S. Kagabu: Pestic. Biochem. Physiol. 62, 172-178 (1998).

13) K. Kiriyama, K. Iwaya, S. Kagabu and K. Nishimura: $J$. Pesticide Sci. 26, 55-59 (2001).

14) T. Suzuki and J. Miyamoto: Pestic. Biochem. Physiol. 4, 8697 (1974).

15) S. Nakagawa, N. Okajima, K. Nishimura, T. Fujita and $M$. Nakajima: Pestic. Biochem. Physiol. 17, 259-270 (1982).

16) K. Nishimura, Y. Kanda, A. Okazawa and T. Ueno: Pestic. Biochem. Physiol. 50, 51-59 (1994).

17) M. B. Smith and J. March: "March's Advanced Organic Chemistry," 5th ed., Wiley, New York, Chapter 10, 2001.

\section{要 約}

\section{チアクロプリドと光の非環状類縁体およびシアノグ アニジン誘導体の殺虫活性と神経遮断活性}

利部伸三，東 明子，西村勁一郎

チアクロプリドの非環状類縁体およびシアノグアニジン 関連化合物を合成し，それらのワモシゴギブリに対する殺 虫活性を化合物単独，あるいは代謝阻害剂を併用して注射 法により測定した.単独の場合には,チアクロプリドと 2 種 のシアノグアニジン誘導体が最も高い活性を示し，イミダ クロプリドの 20 分の 1 程度であった.チアクロプリドを含 む含硫黄化合物の活性は，代謝阻害剤の併用により 100 倍 位にまで増大した，他方，シアノグアニジン誘導体の場合 には，代謝阻害剤による増大効果ははるかに小さかった. ワモンゴキブリの摘出神経に対しては，ほとんどの供試化 合物は最初興奮を誘起した後, 遮断効果をもたらした。千 アクロプリドとその非環状類縁体の遮断活性は，イミダク ロプリドのものに匹敵していた。全体としては遮断活性が 高いほど，代謝阻害剂併用条件下での殺虫活性が高くなる 傾向が見られた。 